\title{
Social representations of the school accordinf to students, teachers and people in general: a longitudinal analysis
}

\author{
Profa. Dra. Elisabete Monteiro de Aguiar Pereira (PQ), Marina Carravero Costa (IC)
}

\begin{abstract}
The project aimed at analyzing the social representations that the school has for teachers and students of Basic Education (Elementary and High School), and for non-academic people. The data resulted from a longitudinal survey developed since 2007 to 2014, through interviews with two questions: "How importante is school?" and "Does the school fulfill its role? Why?". The interviews were split in three segments and there were 991 participants as follows: 335 students, 335 common people and 321 teachers. Being aware of these perceptions and checking the diferences between what teachers, students and ordinary people think can help us undestand the current social behavior towards school as na educational institution.
\end{abstract}

Key words: social representation; school institution; students/teachers/people.

\section{Introduction}

The survey examined perceptions of teachers, students and non-academic people, about the importance of the school institution and how they evaluate the fulfillment of its social role.

The work is based on the Theory of Social Representation (TSR) which, according to Moscovici (1994), is a way of personal knowledge that aims at the development of behaviors and communication among individuals. Its main feature is the imagistic, symbolic, significant, autonomous, creative and constructive character.

\section{Results and Discussion}

The data were collected from the interviews, which were grouped in categories according to the content analysis method proposed by Bardin (2009).The question "How important is school?" brought up five major answer categories shown in the table below.

Chart 1. The importance of school.

\begin{tabular}{|c|c|c|c|}
\hline Categories & Students & Teachers & People \\
\hline $\begin{array}{c}\text { Teaching and } \\
\text { Formation }\end{array}$ & $35 \%$ & $32 \%$ & $35 \%$ \\
\hline $\begin{array}{c}\text { Socialization and } \\
\text { Citzenship }\end{array}$ & $24 \%$ & $40 \%$ & $31 \%$ \\
\hline $\begin{array}{c}\text { Humanistic } \\
\text { Formation }\end{array}$ & $13 \%$ & $21 \%$ & $22 \%$ \\
\hline $\begin{array}{c}\text { Future } \\
\text { Expectations }\end{array}$ & $18 \%$ & $6 \%$ & $11 \%$ \\
\hline No importance & $1 \%$ & $2 \%$ & $1 \%$ \\
\hline
\end{tabular}

"Does the school fulfill its role? Why?" The answers to these questions were divided into four broad categories, found in Table 2.
Chart 2. Fulfillment of the Role of the School.

\begin{tabular}{|l|l|l|l|}
\hline Categories & Students & Teachers & People \\
\hline Yes & $36 \%$ & $11 \%$ & $12 \%$ \\
\hline Yes, but & $15 \%$ & $15 \%$ & $19 \%$ \\
\hline Partially & $26 \%$ & $34 \%$ & $24 \%$ \\
\hline No & $21 \%$ & $39 \%$ & $45 \%$ \\
\hline No answer & $2 \%$ & $2 \%$ & $1 \%$ \\
\hline
\end{tabular}

Regarding the analysis of each category and the subsequent subcategories, it was possible to draw to some assumptions made at the beginning of the project and also to turn down others about the different perceptions of the subjects and between the three groups of subjects concerning the school institution today.

\section{Conclusions}

It was noticed that although the subjects belong to different groups, most of them give a positive significance to school. As for the fulfillment of the role of the institution, most of teachers and people stated that the role has not been effective, whereas students demonstrate proper functioning of the institution.

\section{Acknowledgement}

I thank Professor Elizabeth for the her precious time dedicated to me during the development of my Scientific Initiation Project (SI) and my family for supporting me all the time.

BARDIN, L. Análise de Conteúdo. Lisboa, Portugal; Edições 70, LDA, 2009.

MOSCOVICI, Serge. Introduccion a el campo de la psicologia. In: MOSCOVICI, S. (ed), Representações Sociais. Petrópolis: Vozes, 1994. 